Article

\title{
European Funds in Tourism Sustainability-A Case Study of Beneficiaries' Satisfaction Regarding the Process of Accessing
}

\author{
Anamaria-Cătălina Radu ${ }^{1}$, Ivona Stoica (Răpan) ${ }^{1, *}$, Aida Catanã ${ }^{2}$, Andra-Victoria Radu ${ }^{3}$ and \\ Monica-Lavinia Dan ${ }^{1}$ \\ 1 Institute of National Economy, Romanian Academy, 050711 Bucharest, Romania; \\ anamaria_radu15@yahoo.com (A.-C.R.); lavinia.monica.dan@gmail.com (M.-L.D.) \\ 2 Faculty of Management, "Andrei Saguna” University, 900196 Constanta, Romania; apcatana@gmail.com \\ 3 Faculty of Medicine, University of Medicine and Pharmacy "Carol Davila", 050474 Bucharest, Romania; \\ andra352002@yahoo.com \\ * Correspondence: stradivonas@gmail.com; Tel.: +40-733503338
}

\section{check for} updates

Citation: Radu, A.-C.; Stoica (Răpan), I.; Catanã, A.; Radu, A.-V.; Dan, M.-L. European Funds in Tourism Sustainability-A Case Study of Beneficiaries' Satisfaction Regarding the Process of Accessing. Sustainability 2021, 13, 9109. https:/ / doi.org/10.3390/su13169109

Academic Editors: Eduard

Gabriel Ceptureanu, Ovidiu Bordean and Violeta Radulescu

Received: 18 June 2021

Accepted: 4 August 2021

Published: 14 August 2021

Publisher's Note: MDPI stays neutral with regard to jurisdictional claims in published maps and institutional affiliations.

Copyright: (c) 2021 by the authors. Licensee MDPI, Basel, Switzerland. This article is an open access article distributed under the terms and conditions of the Creative Commons Attribution (CC BY) license (https:// creativecommons.org/licenses/by/ $4.0 /)$.

\begin{abstract}
The scope of this research was to identify the degree of satisfaction experienced by beneficiaries as a result of accessing and implementing a project using European funds in tourism. The whole research identified more than 1000 projects that were financed from European funds in tourism in the period 2007-2013 through the operational programs. The survey was conducted on a sample of 312 respondents, and the method used was a quantitative, research-based survey. This research aims to collect the necessary data for understanding how the process of accessing European funds in tourism is perceived. A few important objectives, such as the effect of the benefits perceived by beneficiaries as a result of accessing projects using European funds in tourism on the degree of satisfaction experienced by them as a result of their development and the effect of risks perceived by beneficiaries as a result of accessing European funded projects in tourism on the degree of satisfaction experienced by them as a result of their development, were highlighted in this research. The most important objective proposed in this research is strategic planning, which is the main way in which the beneficiaries can be fulfilled in regards to the process of accessing European Funds.
\end{abstract}

Keywords: sustainability; European funds in tourism; beneficiary satisfaction; quantitative research; conceptual model

\section{Introduction}

The integration of European funds in tourism and sustainability is a greatly debated topic because of this huge and attractive industry but also for recovery within the pandemic. This means we need new strategies and operational plans based on econometric models and correlations to improve the accessing process for the beneficiaries' satisfaction and to encourage initiatives. The main objective of marketing in tourism is to meet the needs and wishes of consumers in a superior way. In this context, understanding the dimensions of consumer behavior [1] and satisfaction is important [2,3]. Field research has shown that users' satisfaction quickly leads to their loyalty [4-6] and leads to a return to the destination [7-11]. In the literature, we meet three approaches to satisfaction measurement: meeting expectations, benchmarking, and direct assessment [12]. Thus, in this condition, it should be noted that marketers should orient their strategies so as to satisfy the needs and wishes of consumers in a superior way $[13,14]$. An important role in improving customer service is also their involvement in making the packages they want. Thus, the beneficiaries in accessing European funds must identify the priority directions and the most eligible open calls because in tourism, people have distinct needs and desires; it is very important for them to be able to build their own packages together with the company's staff [15]. If the beneficiaries collaborate with a company, they must follow the needs of the company 
and the region to develop and also to follow the needs of people if they are the target of the opened call.

Marketing planning in tourism [16] has great importance, providing enterprises with all the information they need to draw up their strategic and tactical plans [17] (pp. 241-247). Previous research in the field of tourism has shown that, in the marketing-planning process, it is very important that all departments within the organization communicate with each other so that each of them can react in case of unforeseen situations. This can be applied in the field of tourism both at the destination level and at the level of service providers [18] (pp. 258-281). Some authors believe that when applying marketing planning at the destination level, it should be regarded as a tourism organization that aims to meet the needs and wishes of the market [19].

Like in any other field, in order to achieve these plans, tourism requires a careful analysis at both micro and macro levels [20,21]. As a result of the studies developed in tourism organizations, it has been observed that they have the opportunity to set out the strategies and tactics they want to follow in the near future, taking into account a number of criteria. Usually, they are chosen considering the organization resources and the proposed objectives [21]. In addition, when marketing strategies are being implemented, we must take into account both the markets on which the organization operates and the existing competitors [22] (pp. 37-47). Having a clear picture of the environment in which they operate, managers can make the best decisions about marketing activity in the organization.

In addition, the analysis conducted in financial and marketing departments should provide a clear vision of the organization's activity and support the implementation of the chosen strategies $[23,24]$.

\section{Literature Review}

In an era in which technologies are constantly changing $[25,26]$ and the needs and desires of consumers are increasingly diversified, marketing and, implicitly, planning start to hold a much more important place in organizations $[27,28]$. A few representative studies have shown that marketing is no longer seen as a mere activity but as a strategic function that has the role of creating and providing innovative solutions to organizations [29-31].

Strategic marketing has increasing importance in companies [32,33] and provides managers with basic information in decision making [34]. Marketing establishes the value that must be conveyed to customers, the way in which they must be satisfied [35], the way in which long-term relationships with them must be established, etc. [36,37]. The value offered to customers has begun to occupy an increasingly important place in this field of activity, with consumers giving importance to the additional elements they receive after purchasing various products or services [38] (pp. 69-71).

Marketing planning $[39,40]$ is defined in the literature [41] (p. 152) as "a complex process that includes successive operational stages, values, and assumptions in which, based on the existing analysis of a company, its strategic objectives, the means by which they may be achieved and the possibilities for assessing their level of completion, are identified and established." In order to observe the role and necessity of marketing planning in an organization, some authors conducted various studies through which they tried to determine the differences between companies that plan their marketing activity and those that modify their activities according to existing influences from the external environment. In addition, some of them have tried to build inductive marketing-planning models to support managers in their work. These were intended to illustrate the factors that firms should focus on in order to achieve the best possible market position [42-44].

Studies have shown that organizations that apply the principles of marketing planning perform much better than those that do not use this concept. The results of these studies have led many authors to mention that marketing planning offers a number of benefits to businesses, as they have the ability to achieve much better results financially. However, managers need to be aware that the results of marketing planning can only be seen over a 
longer period of time and not immediately, as planning aims to achieve long-term and not short-term goals [45].

Sustainable marketing refers to the marketing mix elements, and one of the important components is promotion practices and values at the social and environmental pillars. It refers to $100 \%$ recyclable products or products that can be manufactured locally. They have a higher cost precisely for these reasons, whether they are made from raw materials that are only found in certain geographical locations or can be recycled and have a considerably reduced negative impact on the environment.

More and more companies are beginning to focus on sustainability and giving due respect to the nature without placing an emphasis on production in terms of quantity. Thus, sustainable production is encouraged, and the advantage lies on both sides of the balance sheet; both the environment and the company are able to gain. In this case, since the emphasis is on sustainability and not on producing as much as possible in a short time, the environment is able to gain because the amount of resources being used decreases significantly, and other elements necessary for the production process, such as electricity, will have lower costs.

Sustainable marketing, in comparison to traditional marketing, shows the existent properties of a product without creating new ones in order to sell it faster. Sooner or later, all companies will have to resort to sustainable marketing, at least because of the limited resources that the environment can generate. The Brundtland report refers to sustainable development as "development that meets the needs of the present without compromising the ability of future generations to meet their own needs" [46]. In this way, today's generations can use the necessary resources to meet their needs without depriving the environment of all its resources, thus allowing future generations to have a life at least as good as theirs. For example, the production of copier paper required will be met but without causing irreversible damage to the environment and massive deforestation. Sustainable marketing is seen as the fusion of green, ethical, and social marketing with a long-term impact on the social and environmental pillars [47,48].

Sustainable development has three pillars: economic (the companies' and enterprises' capability of sustaining their activity on the long term), social (equal benefits distribution and mitigation of poverty), and environmental (preservation of natural resources). Sustainability and sustainable development are, in some cases, used in alteration [49]: sustainable development refers to the process leading to the achievement of sustainability [50].

There is a confusion between the nature of the alternative use of the concepts of sustainability, sustainable development, and green marketing. Some researchers mentioned that sustainability and sustainable marketing are two different concepts [51,52], while others have used them interchangeably. The same is true for green marketing with sustainability and sustainable marketing [53,54]:

Tourism has great potential to speed up progress across the economic sectors in a sustainable manner; through integrated policies, tourism can generate quality employment opportunities for durable economic and social growth, hence reduce poverty and provide encouragement for environmental protection, and thus offer a triple-win situation for nations to move toward an inclusive and resilient economy. [55]

The role of sustainability in tourism development is very critical because tourism is a significant factor in resource use, global environmental, and social change. [56]

Economic growth would be the result, among other things, of the expansion of the tourism sector, tourism creates links between economic sectors and its development facilitates the propagation of economic effects that are wider than the direct ones we usually consider, ignoring the related ones. [57] 


\section{Materials and Methods}

\subsection{Scope of the Research}

The scope of this research is to identify the degree of satisfaction experienced by beneficiaries as a result of accessing and implementing a project using European funds in tourism for the period 2007-2013. This research aims to collect the necessary data for understanding how the process of accessing European funds to tourism is perceived. In addition, the results can contribute to reviewing this process over the period 2014-2020 so that the results obtained from the implementation of the projects are some of the best. By highlighting the benefits and risks perceived by the beneficiaries, managers of different programs will know what they are supposed to do and the attributes they need to take into account to reduce the perceived risks. In addition, they can identify the techniques and web tools perceived by the beneficiaries as having a particular importance in the process of accessing European funds in tourism. The research also illustrates how the implementation of marketing planning in the projects financed by European funds in tourism has the ability to influence the degree of satisfaction subsequently experienced by the beneficiaries. In this way, the most appropriate structure of projects can be identified so that the results obtained from their implementation will have a stronger impact on the development regions where they are implemented.

\subsection{Research Sample}

The survey was conducted on a sample of 312 respondents (project managers); the method used was a quantitative, research-based survey. The collectivity research is represented by the all beneficiaries that accessed, at the time of writing, at least one EU fund grant in tourism during the period 2007-2013. Referring to the period 2014-2021, according to previous research, we noticed a lower rate of integration of EU funds. The observing unit is equal to the survey unit in which the subjects had the opportunity to apply and develop a tourism EU fund grant. "The instrument used to collect data was the online ad hoc survey" [58].

We used the following formula to identify the sample dimension:

$$
N=\frac{t \times p \times(1-p)}{\Delta \omega^{2}}
$$

$N$-the required size of the sample; $t$-the coefficient associated to the probability of guaranteeing results; $p$-the share of respondents with the required characteristics; maximum admitted error (limit of error).

We set the sampling size considering the following parameters: a coefficient associated to the probability of guaranteeing results of $95 \%(t=1.96$, respectively); maximum admitted error of $5 \%$ with $p$ value of 0.5 .

\subsection{Survey Design}

The entire research identified more than 1000 projects developed by the subjects, who were project managers or top management (survey unit), who were financed from European funds in tourism in the period 2007-2013 through the operational programs POR, PNDR, and POSDRU. It is worth mentioning that the beneficiaries were able to access one, two, or more projects funded through these programs. The databases comprising the representatives of the projects funded by European funds in tourism have been obtained both from the online environment and from the authorities operating in this field.

The method by which the proposed research model was estimated is the so-called method of variation. The analysis was done by using the Warp-PLS 3.0 software, which uses the smallest square technique. At this point in the analysis, the regression algorithm "Warp3 PLS regression" was chosen. This method is very important, allowing for the determination of the curvilinear relationships between the S- and U-shaped model variables.

The questionnaire made for this study includes 30 questions, which had the role of fulfilling the purpose of the research. The first question was a filter and aimed at selecting 
beneficiaries who accessed at least one project funded by European funds in tourism in the period 2007-2013. The following nine questions aimed to identify the characteristics that defined the subjects. In the questionnaire, there were several questions specific to the 10 latent variables studied in the proposed econometric model. Each latent variable corresponds to several items, according to which the respondents were instructed to express their agreement/disagreement. The 7-step Likert scale was used for the measurement. At the end of the questionnaire, six questions were used to build the demographic profile of the respondents.

\subsection{Regression Model}

Conceptually, the research contributes by using a regression model to analyze the intensity of the relationship between factors. In terms of the connection types existing at the level of analyzed dependent and independent constructs, the conceptual model can be described as a multiple regression model:

Satisfaction $(x)=\beta_{0}+\beta_{1}{ }^{*} \operatorname{Benefits}\left(x_{1}\right)+\beta_{2}{ }^{*}$ Risks $\left(x_{2}\right)+\beta_{3}{ }^{*}$ Communication $\left(x_{3}\right)+$ $\beta_{4}{ }^{*}$ Technologies $\left(x_{4}\right)+\beta_{5}{ }^{*}$ Planning $\left(x_{5}\right)+\beta_{6}{ }^{*}$ Perceptiveness $\left(x_{6}\right)+\beta_{7}{ }^{*}$ Promotion $\left(x_{7}\right)+\beta_{8}{ }^{*}$ Attitude $\left(x_{8}\right)+\beta_{9}{ }^{*}$ intention $\left(x_{9}\right)+\beta_{10}{ }^{*}$ interpersonal promotion $\left(x_{10}\right)$

\subsection{Constructs and Items}

The hypotheses raised are supported by the previous literature, which concerns the conceptual definition of the constructs we have chosen as relevant items for each latent variable, and we reviewed the SERVQUAL model [59], TPB model [60], SaaS-QUAL model, and TAM model (Technology Acceptance Model), which we had also done in previous research.

The conceptual model comprises the following constructs:

(a) The perceived benefits (Benefits) represent the first latent variable measured in the study. They aim to pass on the advantages that the beneficiaries of the projects financed from European funds in tourism consider to have obtained as a result of their implementation. This is a formative variable measured using the 7-step Likert scale. The formative construct is based on five items: the possibility to start a tourism business, the possibility to improve/expand the accommodation/food or leisure unit owned, the possibility to improve the tourist activity in the project implementation area, the possibility to contribute to the economic development of the tourist destination and of the development region at the level of which the project financed from European funds were implemented, as well as the contribution to the increase of the number of jobs at its level.

(b) The perceived risks (Risks) have also been previously analyzed by a number of specialists in the field, reflecting to a large extent the fears that respondents have about a number of variables from the external or internal environment that may affect their activity when accessing projects financed from European funds in tourism or during their implementation. The formative construct is based on six items: the allocation of resources for the implementation of the project was carried out in the terms established in the project; the time allotted for making the (deliverable) reporting materials was sufficient; the specialized training of the experts employed in the implementation of the activities was adequate; clear and correlated definition of the activities undertaken through the project; reporting a limited number of documents during the implementation period as well as the fact that during the implementation of the project, no new instructions appeared to regulate the activity developed at the project level.

(c) Communication with those within the Managing Authority (MA). In the field of accessing European funds in tourism, the communication process with those within the Managing Authority is very important, as it facilitates the transmission and reception of the necessary information and documents during the implementation process. For this latent variable, we selected eight items: good communication between the two parties during the project; receiving permanent feedback from project representatives during its development; the time to receive the necessary information about the project was 
short; receiving counseling services during the project; the information provided by the beneficiary's guide was sufficient to ensure the progress of the project; obtaining the same feedback regardless of the person contacted; providing technical support for uploading documents on the platform; the communication through the Help Desk system of the Managing Authority was prompt and complete.

(d) Web technologies and tools are those that facilitate the transmission of information, notifications, or supporting materials enabling the contact between the parties and allowing them to have instant access to the information transmitted. The formative construct was built around seven items that aimed to identify the way in which project beneficiaries perceive the web tools and technologies they came in contact with during the implementation process. The items used covered the following aspects: the normal operation of the Action Web reporting platform; highlighting comments on claims for reimbursement/payment and approved eligible expenditure and expenditure declared ineligible; providing automatic answers to frequently asked questions through the Help Desk system; the efficiency of communication by e-mail; the importance of the Management Authority (MA) website in providing information to beneficiaries; the importance of social networks in providing information to beneficiaries; the importance of specialized forums in providing information to beneficiaries.

(e) The use of marketing planning in the process of accessing projects financed from European funds (Marketing planning). Through this, we wanted to illustrate the way in which the application of the principles of marketing planning for projects financed from European funds has the capacity to influence the satisfaction of the beneficiaries. Seven items were considered for this variable. The seven existing items at the level of this construct concerned the following: the existence of a marketing plan included in the business plan through which the project financed from European funds in tourism was accessed; the usefulness of the marketing plan realized in the implementation of the project; specifying in the marketing plan the financing sources used; carrying out within the marketing plan an environmental analysis in which the project will take place; specifying in the marketing plan the objectives to be pursued; specifying in the marketing plan the strategies pursued; specifying the estimated results within the marketing plan.

(f) Receptiveness of the staff within the Managing Authority (MA)—(Staff). Through this, we wanted to observe how the openness and receptiveness of the staff have the ability to influence the degree of satisfaction felt by the beneficiaries regarding the process of accessing European funds. At the level of this variable, seven items were formulated, targeting the following: efficient management of the problems by the Managing Authority so that the beneficiaries have the possibility to quickly obtain the necessary information; promptness of employees in solving problems encountered; providing complete information on the launch of applications for projects financed from European funds in tourism; ensuring by the Managing Authority (MA) the evaluation of projects, the display of results and the signing of financing contracts; the ongoing support provided by MA employees, project beneficiaries, and the time allocated by MA employees to solve problems posed by beneficiaries.

(g) Project promotion. Through this, we wanted to identify how the promotion carried out within the project had the ability to influence the degree of satisfaction felt by users after accessing and implementing a project funded by European funds in tourism. This latent variable was based on four items aiming to identify the following attributes: the usefulness of the launch conference; the contribution of promotional materials to the knowledge of the activities and results of the project; how the online promotion ensured the operational information of the target group; popularizing the results of the project during the launch conference.

(h) Normative attitude. This concerned the way in which beneficiaries were influenced by those close to them before accessing the project financed from European funds in tourism. At the level of this variable, seven items were built: the influence of the family on the decision to access a project financed from European funds in tourism; the influence 
of friends on the decision to access a project funded by European funds in tourism; the influence of the relevant Ministry on the decision to access a project financed from European funds in tourism; the influence of local authorities on the decision to access a project financed from European funds in tourism; the influence of the Managing Authority (MA) on the decision to access a project financed from European funds in tourism; the influence of the beneficiary's guide on the decision to access a project financed from European funds in tourism; the influence of consulting firms on the decision to access a project financed from European funds in tourism.

(i) Satisfaction of beneficiaries. This illustrates, in fact, how the provision of services in this area has risen to the level of expectations of beneficiaries. To measure the satisfaction of the beneficiaries, four items were used to identify the degree of satisfaction of the beneficiaries regarding the way in which the process of accessing the projects financed from European funds in tourism took place: the degree of the delight of the beneficiaries regarding the way in which the process of accessing the projects financed from European funds in tourism took place; the joy felt by the beneficiaries regarding the way in which the process of accessing the projects financed from European funds in tourism took place; the degree of satisfaction felt, in total, by the beneficiaries regarding the way in which the process of accessing the projects financed from European funds in tourism took place.

(j) Intention to re-access. This variable indirectly illustrates the degree of satisfaction that the beneficiaries felt after accessing these projects. Thus, the more satisfied they are, the more they will intend to re-access such projects in the future. At the level of this variable, three items were used that aimed to identify the possibility of beneficiaries to access such projects: the intention of beneficiaries to access such projects, the desire of beneficiaries to access such projects, the hope of beneficiaries to access such projects.

(k) Interpersonal promotion. This variable refers to the intention of the beneficiaries to recommend such projects to those close to them. At the level of this variable, three items were used as follows: the possibility for the beneficiaries to recommend the projects financed from European funds in tourism; the desire of the beneficiaries to recommend the projects financed from European funds in tourism; as well as the intention of the beneficiaries to recommend the projects financed from European funds in tourism.

All the construct items were measured on a 7-point Likert scale.

The following research hypotheses were formulated:

Hypotheses 1. The benefits perceived by the beneficiaries following the accessing of projects financed from European funds in tourism have a direct and positive effect on the degree of satisfaction that they feel.

Hypotheses 2. The risks perceived by the beneficiaries following the accessing of projects financed from European funds in tourism have a direct and negative effect on the degree of satisfaction that they feel.

Hypotheses 3. The communication process between the beneficiaries and the Managing Authority (MA) has a direct and positive effect on the degree of satisfaction that they feel following the development of projects financed from European funds in tourism.

Hypotheses 4. Technologies and web tools have a direct and positive effect on the degree of satisfaction felt by beneficiaries following the development of projects financed from European funds in tourism.

Hypotheses 5. Marketing planning has a direct and positive effect on the degree of satisfaction felt by beneficiaries following the development of projects financed from European funds in tourism.

Hypotheses 6. The receptiveness of the staff within the Managing Authority (MA) has a direct and positive effect on the degree of satisfaction felt by the beneficiaries following the development of projects financed from European funds in tourism. This variable has been previously measured in the SERVQUAL model [57]. 
Hypotheses 7. The promotion of the project has a direct and positive effect on the degree of satisfaction felt by the beneficiaries following the development of projects financed from European funds in tourism.

Hypotheses 8. The normative attitude has a direct and positive effect on the degree of satisfaction felt by the beneficiaries following the development of projects financed from European funds in tourism. This variable has been previously measured in the TPB (Theory of Planned Behavior) model [58].

Hypotheses 9. The degree of satisfaction felt by the beneficiaries following the development of projects financed from European funds in tourism has a direct and positive effect on their intention to re-access such projects in the future.

Hypotheses 10. The degree of satisfaction felt by the beneficiaries following the development of projects financed from European funds in tourism has a direct and positive effect on their interpersonal promotion in the future.

The method used in the estimated model of the research was the variation. The analysis was done using the Warp-PLS 3.0, OLS technique. At the analysis, we chose the regression algorithm "Warp3 PLS regression". This method is very important to determine the curvilinear relations between the variables of the U- and S-shaped models.

\section{Results and Key Findings}

In order to observe if the constructs presented in the conceptual model influence the satisfaction of the respondents regarding the process of accessing and implementing the project using European funds in tourism, we assessed the beta coefficients and the significance in Table 1. These two coefficients were used to validate or invalidate the research hypotheses.

Table 1. Testing the hypotheses.

\begin{tabular}{|c|c|c|c|c|}
\hline & Hypothesis & $\beta$ & $p$ & Condition \\
\hline $\mathrm{H} 1$ & Perceptiveness Benefits-Satisfaction & 0.190 & $<0.001$ & Validated \\
\hline $\mathrm{H} 2$ & Perceptiveness risks-Satisfaction & 0.203 & $<0.001$ & Validated \\
\hline $\mathrm{H} 3$ & $\begin{array}{c}\text { Communication with MA (Management } \\
\text { Authority)—Satisfaction }\end{array}$ & 0.193 & $<0.001$ & Validated \\
\hline $\mathrm{H} 4$ & $\begin{array}{l}\text { Online tools and web } \\
\text { technologies-Satisfaction }\end{array}$ & 0.136 & $<0.001$ & Validated \\
\hline $\mathrm{H} 5$ & Marketing planning-Satisfaction & 0.145 & $<0.001$ & Validated \\
\hline H6 & $\begin{array}{l}\text { Perceptiveness of MA (Management } \\
\text { Authority)—Satisfaction }\end{array}$ & 0.142 & $<0.001$ & Validated \\
\hline $\mathrm{H} 7$ & Project promotion-Satisfaction & 0.045 & $<0.21$ & Not Validated \\
\hline $\mathrm{H} 8$ & Regulative attitude-Satisfaction & 0.043 & $<0.22$ & Not Validated \\
\hline H9 & Re-accessing intention & 0.861 & $<0.001$ & Validated \\
\hline H10 & Satisfaction-Interpersonal promotion & 0.881 & $<0.001$ & Validated \\
\hline
\end{tabular}

From the table above, it can be noted that 8 of the 10 hypotheses existing in this research are validated. This means that the value of beta coefficients is greater than 0.1 , while significance thresholds are less than 0.05 . The hypothesis H7 is rejected, with a $p$-value greater than $0.05(0.21)$, while the value of $\beta$ is 0.045 . Another hypothesis that was rejected in the research is H8. It had recorded a $p$-value of 0.22 , and $\beta$ had the value of 0.043 .

Another indicator analyzed in this model is the determination coefficient R2 (Table 2). This indicator suggests the extent to which the independent variables from the (exogenous) 
model have the ability to explain the variance of the dependent (endogenous) variables. Their value was calculated only for the dependent variables of the model.

Table 2. The determination coefficients.

\begin{tabular}{ccc}
\hline Satisfaction Beneficiaries & Re-Accessing Intention & Interpersonal Promotion \\
\hline 0.829 & 0.742 & 0.775 \\
\hline
\end{tabular}

The obtained values show that the independent variables presented in the proposed conceptual model have the ability to explain to a high degree the variance of the dependent variables. Thus, the beneficiaries' satisfaction with the process of accessing European funds in tourism is explained in a proportion of $82.9 \%$ by the independent variables presented. The intention of the beneficiaries to recommend future such projects funded by European funds in tourism is explained $74.2 \%$ of their satisfaction, while the interpersonal promotion variable is explained $77.5 \%$ by the satisfaction of the beneficiaries.

The Warp-PLS program provides users with the opportunity to obtain some model compliance metrics.

The obtained values showed us that independent variables are presented at the level of the conceptual model proposed and are able to explain, in a higher measure, the variation of the dependent variables. Therefore, we took into account the highest variables of the $\mathrm{R} 2$ where the independent variables had the higher capacity to explain the endogenous variables. The coefficient $\mathrm{R} 2$ was calculated to observe the relationship between constructs, overall, at the level of the model; also taken into account were other indicators presented in Table 3 in order to explain the validity of the tested model.

Table 3. Conformity measurement coefficients.

\begin{tabular}{lc}
\hline \multicolumn{1}{c}{ Indicators } & Validation Criteria \\
\hline Average path coefficient (APC) $=0.284$ & $p<0.001$ \\
\hline Average R-squared (ARS) $=0.782$ & $p<0.001$ \\
\hline Average adjusted R-squared (AARS) $=0.780$ & $p<0.001$ \\
\hline Average VIF (AVIF) $=2.996$ & Threshold $<5$, Ideally $<3.3$ \\
\hline Average full co linearity VIF (AFVIF) $=4.773$ & Threshold $<5$, Ideally $<3.3$ \\
\hline Tenenhaus GoF $($ GoF) $=0.727$ & Threshold $>0.7$, Ideally $=1$ \\
\hline Sympson's paradox ratio (SPR) $=1.000$ & Threshold $>0.9$, Ideally $=1$ \\
\hline R-squared contribution ratio (RSCR) $=1.000$ & Threshold $>0.7$ \\
\hline Statistical suppression ratio (SSR) $=1.000$ & Threshold $>0.7$ \\
\hline $\begin{array}{l}\text { Nonlinear bivariate causality direction ratio } \\
\text { (NLBCDR) }=1.000\end{array}$ & \\
\hline
\end{tabular}

In order to validate a model through structural equations using the PLS variation method, a series of guidelines should be observed, such as $p$-values associated with APC, ARS, and AARS are less than 0.05; the value of AVIF and AFVIF is less than 5; the value of GOF is greater than 0.36; the SPR value is higher than 0.7; the RSCR value is higher than 0.9 ; and the value of SSR and NLBCDR is greater than 0.7.

From the table presented above, it can be noted that the conformity indicators of the model obtained from the analysis recorded very good values, falling within the abovementioned values. In view of the above, we can mention that the proposed model is validated by the variation method. 


\section{Discussion and Conclusions}

The conceptual model proposed in this paper aimed to test how the beneficiaries' satisfaction with the process of accessing European funds in tourism is influenced by a series of factors, such as perceived benefits, perceived risks, communication with the Management Authority (MA), web technologies and tools, marketing planning of European funds, receptiveness of the Management Authority, project promotion, and regulative attitude. In addition, through this research, we wanted to identify how the satisfaction of the beneficiaries has the ability to influence their intention to respond to such projects as well as their intention to promote them among those close to them.

The model created and tested in the paper presents a number of implications both theoretical and practical. In terms of theoretical contributions, it should be noted that, most importantly, this study refers to the proposal and validation from an econometric perspective of a unique model in the literature. So far, no such model that observes how a number of factors have the capacity to influence beneficiaries' satisfaction with the process of accessing European funds in tourism has been created theoretically. In the proposed conceptual model, there were 10 main assumptions, of which only eight were accepted. Additionally, the coefficients $\beta$ and the determination coefficients R2 were estimated to observe the degree of influence of the independent variables on the dependent ones.

\subsection{Discussion}

From the analysis presented, it was observed that beneficiaries' satisfaction is influenced to a large extent by perceived benefits, perceived risks, communication with the Management Authority, web technologies and tools, marketing planning of European funds, and the receptiveness of those in the Management Authority. The $p$-value was more than 0.05 for two variants: promotion of the project and normative attitude. The indicators show that they do not have the ability to directly and positively influence the degree of satisfaction experienced by users following the process of accessing European funds in tourism.

At the level of the analysis, the coefficient R2 was also analyzed. Thus, it was noted that beneficiaries' satisfaction with the process of accessing European funds to tourism is explained $83 \%$ by the variables analyzed. Moreover, their intention to respond to such projects in the future is explained $74 \%$ by the satisfaction of the beneficiaries, while the interpersonal promotion variable is explained in a proportion of $78 \%$ by the variable satisfaction. In view of the above, we believe that the purpose and objectives of the study have been met. Thus, the main factors that have the capacity to influence the satisfaction felt by the beneficiaries as a result of accessing a project funded by European funds in tourism were observed. Moreover, the model presented in the paper was validated, and the resulting conformity indicators obtained very good values.

The indicators presented in the model have shown that there is a direct and positive link between the technologies used in the process of accessing European tourism funds and the degree of satisfaction felt. Thus, as these web technologies and tools work better to facilitate the process, the higher the degree of satisfaction [61]. Another validated hypothesis showed that there is a direct and positive link between how recipients plan the process of accessing European funds and the degree of contentment felt. This shows that the more often users use the planning process and the more they use the principles of the process, the higher the level of satisfaction [62].

Another variable that has the ability to influence user satisfaction is the responsiveness of employees of the Management Authority. The study showed that the more open the staff of the Management Authority and the more receptive to communicating with project beneficiaries, the higher the level of satisfaction felt by the beneficiaries. Instead, if they are not interested in solving the problems faced by the beneficiaries, the degree of satisfaction decreases. In addition, from the analysis, we noticed that the degree of satisfaction felt has the ability to directly influence the intention of the beneficiaries to respond to such projects. The higher the degree of contentment, the greater the intention to respond to such projects. 
Moreover, the degree of resulting contentment has the ability to also influence their desire to promote such projects among those close to them. If the beneficiaries are more satisfied, their intention to promote such projects is greater.

As mentioned above, the compliance metrics obtained in this model have shown that the proposed model is approved. In view of the above, we believe that the results obtained in this paper bring added value both in practical and theoretical terms. However, in order to obtain a thorough overview of the subject under discussion, other studies of a quantitative nature should be carried out to confirm or refute those presented.

\subsection{Conclusions}

In terms of practicality, we note that this work brings added value, showing the main points that managers of the Management Authority should focus on to increase the level of satisfaction experienced by beneficiaries of projects funded by European funds in tourism. In order to increase the absorption rate and achieve the best results from the implementation of such projects, all aspects presented should be considered. From the model presented, we have noticed that the benefits perceived by the beneficiaries have a strong impact on the satisfaction of individuals. Thus, the more they perceive these advantages, the more satisfied they are. In terms of risks, it has been noted that risks negatively influence the degree of contentment felt. The more risks perceived, the lower the satisfaction level, and the lower the perceived disadvantages, the higher the satisfaction level. Another variable that influences the satisfaction of the beneficiaries of European funds in tourism is communication with the Management Authority. As a result of the analysis, it was noted that the easier the communication process and the more easily the information circulates between the two parties, the higher the level of satisfaction.

\subsection{Limits of the Research}

In addition to the important results that were obtained at the research level, it should be mentioned that they also have some limitations. Thus, one of the most important refers to the way in which the data were collected. As the research tool was distributed online, we are not sure that it was completed exclusively by subjects who were involved in projects funded by European funds in tourism. Moreover, the quantitative study was conducted on a small sample of 312 respondents. In order to better understand this field and to have a much clearer picture on the analyzed subject, other studies should be carried out on a larger number of respondents, which should present in detail the perception of the beneficiaries involved in this field of activity.

Another limitation of the research refers to the variables that were taken into account. Thus, at its level, eight variables were studied that have the ability to influence the satisfaction of beneficiaries. In addition, there may be others that have not yet been considered. For this reason, other variables that are intended to influence the satisfaction of the beneficiaries of European funds in tourism should be analyzed at the level of subsequent studies.

As for the future directions of the research, they have as a starting point the limits mentioned above. In order to increase the quality of the quantitative study, an analysis should be performed on a larger number of respondents that would allow us to extrapolate the results to the entire research community.

Future research should be based on several qualitative studies upon which to build the basis of quantitative research. They should take into account several variables that have the potential to influence the satisfaction of beneficiaries in the process of accessing European funds in tourism. Future research may also consider studying, in this situation of pandemic, strategies for redressing and resilience.

Author Contributions: Conceptualization, A.-C.R., I.S., and A.C., methodology, A.-C.R. and I.S.; data curation, A.-C.R., I.S., A.-V.R., and M.-L.D.; writing-original draft preparation, A.-C.R., I.S., and A.C.; visualization, A.-C.R., I.S., A.C., A.-V.R., and M.-L.D. All authors have read and agreed to the published version of the manuscript. 
Funding: This research received no external funding.

Conflicts of Interest: The authors declare no conflict of interest.

\section{References}

1. Kozak, M.; Rimmington, M. Tourist satisfaction with Mallorca, Spain, as an off-season holiday destination. J. Travel Res. 2000, 38, 260-269. [CrossRef]

2. Yolal, M.; Chi, C.G.-Q.; Pesämaa, O. Examine destination loyalty of first-time and repeat visitors at all-inclusive resorts. Int. J. Contemp. Hosp. Manag. 2017, 29, 1834-1853. [CrossRef]

3. Yoon, Y.; Uysal, M. An examination of the effects of motivation and satisfaction on destination loyalty: A structural model. Tour. Manag. 2005, 26, 45-56. [CrossRef]

4. Ryu, Y.K.; Park, J.-W. Investigating the effect of experience in an airport on pleasure, satisfaction, and airport image: A case study on incheon international airport. Sustainability 2019, 11, 4616. [CrossRef]

5. Kyle, G.T.; Theodorakis, N.D.; Karageorgiou, A.; Lafazani, M. The effect of service quality on customer loyalty within the context of ski resorts. J. Park Rec. Admin. 2010, 28, 1-15.

6. Zhang, H.; Fu, X.; Cai, L.A.; Lu, L. Destination image and tourist loyalty: A meta-analysis. Tour. Manag. 2014, 40, 213-223. [CrossRef]

7. Nam, J.; Ekinci, Y.; Whyatt, G. Brand equity, Brand loyalty and consumer satisfaction. ATR 2011, 38, 1009-1030. [CrossRef]

8. Meleddu, M.; Paci, R.; Pulina, M. Repeated behaviour and destination loyalty. Tour. Manag. 2015, 50, 159-171. [CrossRef]

9. Oliver, R.L. Satisfaction: A Behavioral Perspective on the Consumer; McGraw-Hill: New York, NY, USA, 1997.

10. Fuchs, M.; Weiermair, K. New perspectives of satisfaction research in tourism destinations. Tour. Rev. 2003, 58, 6-14. [CrossRef]

11. Kozak, M.; Bigné, E.; Andreu, L. Satisfaction and destination loyalty. J. Qual. Assur. Hosp. Tour. 2005, 5, 43-59. [CrossRef]

12. Abrudan, I.-N.; Pop, C.-M.; Lazăr, P.-S. Using a general ordered logit model to explain the influence of hotel facilities, general and sustainability-related, on customer ratings. Sustainability 2020, 12, 9302. [CrossRef]

13. Oliver, R.L. Measurement and evaluation of satisfaction process in retail setting. J. Retail. 1981, 57, $25-48$.

14. Homburg, C.; Koschate, N.; Hoyer, W.D. The role of cognition and affect in the formation of customer satisfaction: A dynamic perspective. J. Mark. Manag. 2006, 70, 21-31. [CrossRef]

15. Liang, R.D.; Zhang, J.S. The effect of service interaction orientation on customer satisfaction and behavioral intention: The moderating effect of dining frequency. Proc. Soc. Behav. Sci. 2011, 24, 1026-1035. [CrossRef]

16. Stăncioiu, A.-F.; Căescu, S.C.; Filip, A.; Ionescu, F.T.; Constantinescu, M. Planificarea De Marketing in Turism: Concepte Si aplicatii; Economica Publishing: Bucharest, Romania, 2005.

17. Whittington, R.; Cailluet, L. The craft of strategy. Long Range Plan. 2008, 41, 241-247. [CrossRef]

18. Liu, Z.; Siguaw, J.A.; Enz, C.A. Using tourist travel habits and preferences to assess strategic destination positioning: The case of Costa Rica. Cor. Hosp. Q. 2008, 49, 258-281.

19. Tribe, J. Strategy for Tourism; Goodfellow Publishers Ltd.: Oxford, UK, 2010.

20. Mullins, L.J. Managing People in the Hospitality Industry; Essex-Addison Wesley Longman: Edinburgh Gate, UK, 1998.

21. Mintzberg, H.; Ahlstrand, B.; Lampel, J. Strategy Safari: A Guided Tour through the Wilds of Strategic Management; Prentice Hall Publishing: London, UK, 1998.

22. Papadopoulos, S.I. Strategy development and implementation of tourism marketing plans: Part 2. Eur. J. Mark. 1989, 23, 37-47. [CrossRef]

23. Kopaneli, A. Finance, marketing, management and strategy planning. A qualitative research method analysis of case studies in business hotels in Patras and in Athens. Procedia Econ. Financ. 2014, 9, 472-487. [CrossRef]

24. Zinkhan, G.; Preira, A. Review: An overview of marketing strategy and planning. Int. J. Res. Mark. 1994, 11, 185-218.

25. Ližbetinová, L.; Štarchoň, P.; Lorincová, S.; Weberová, D.; Pruša, P. Application of cluster analysis in marketing communications in small and medium-sized enterprises: An empirical study in the Slovak Republic. Sustainability 2019, 11, 2302. [CrossRef]

26. Durica, M.; Svabova, L. Improvement of company marketing strategy based on Google search results analysis. Procedia Econ. Financ. 2015, 26, 454-460. [CrossRef]

27. Sánchez-Teba, E.M.; García-Mestanza, J.; Rodríguez-Fernández, M. The application of the inbound marketing strategy on costa del sol planning \& tourism board. lessons for Post-COVID-19 revival. Sustainability 2020, 12, 9926. [CrossRef]

28. McMahan, C.; Hovland, R.; McMillan, S. Online marketing communications: Exploring online consumer behavior by examining gender differences and interactivity within internet advertising. J. Interact. Advert. 2009, 10, 61-76. [CrossRef]

29. Perreault, W.D.; Cannon, J.P.; McCarthy, J. Essentials of Marketing: A Marketing Strategy Planning Approach; McGraw-Hill/Irwin: New York, NY, USA, 2010.

30. Nwokah, G.; Ahiauzu, A.I. Managerial competency and marketing effectiveness in corporate organizations in Nigeria. J. Manag. Dev. 2008, 27, 858-878. [CrossRef]

31. Mavondo, F.T.; Chimhanzi, J.; Stewart, J. Learning orientation and market orientation. Eur. J. Mark. 2004, 39, 1235-1263. [CrossRef]

32. Ittner, C.D.; Larcker, D.F. Are nonfinancial measures leading indicators of financial performance? An analysis of customer satisfaction. J. Account. Res. 1998, 36, 1-35. [CrossRef]

33. Paley, N. Marketing Strategy Desktop Guide; Hawksmere: London, UK, 2000. 
34. Andrijauskiene, M.; Dumciuviene, D. National culture as a determinant of firms' innovative performance. Forum Sci. Oeconomia 2018, 6, 47-67.

35. Esu, B.B.; Arrey, V.M.E. Tourists' satisfaction with cultural tourism festival: A case study of Calabar Carnival Festival, Nigeria. Int. J. Bus. Manag. 2009, 4, 116. [CrossRef]

36. Sirvastava, K.R.; Fahey, L.; Christensen, K.H. The resource-based view and marketing: The role of market-based assets in gaining competitive advantage. J. Manag. 2001, 27, 777-802. [CrossRef]

37. Harmsen, H.; Jensen, B. Identifying the determinants of value creation in the market: A competence-based approach. J. Bus. Res. 2004, 57, 533-547. [CrossRef]

38. Roy, A.; Chattopadhyay, S.P. Stealth marketing as a strategy. Bus. Horiz. 2010, 53, 69-79. [CrossRef]

39. Piercy, N.F.; Morgan, N.A. The marketing planning process: Behavioral problems compared to analytical techniques in explaining marketing plan credibility. J. Bus. Res. 1994, 29, 167-178. [CrossRef]

40. Gilligan, C.; Wilson, R.M.S. Strategic Marketing Planning; Butterworth-Heinemann: Amsterdam, The Netherlands, 2003.

41. Stancioiu, A.-F. Dictionar De Terminologie Turistica; Economica Publishing: Bucharest, Romania, 1999.

42. Nicholas, J.A.; Frederikson, M.; Davies, J. Strategic marketing planning: A grounded investigation. Eur. J. Mark. 2003, 37, 430-460.

43. Botha, C.; Crompton, J.L.; Kim, S.S. Developing a revised competitive position for sun/lost city, South Africa. J. Travel Res. 1999, 37, 341-352. [CrossRef]

44. Wood, M.B. Essential Guide to Marketing Planning; Pearson Education: London, UK, 2007.

45. McDonald, M. Marketing Strategic; Codecs: Bucharest, Romania, 1998.

46. United Nations General Assembly. Report of the World Commission on Environment and Development: Our Common Future; Transmitted to the General Assembly as an Annex to document A/42/427, Development and International Co-operation: Environment; Our Common Future. Chapter 2: Towards Sustainable Development; Paragraph 1. Available online: http: / / www.un-documents.net/wced-ocf.htm (accessed on 13 August 2021).

47. Belz, F.M.; Peattie, K. Sustainability marketing: An innovative conception of marketing. Mark. Rev. St. Gallen 2010, $27,8-15$.

48. Gordon, R.; Carrigan, M.; Hastings, G. A framework for sustainable marketing. Mark Theory 2011, 11, 143-163. [CrossRef]

49. Hugé, J.; Waas, T.; Dahdouh-Guebas, F.; Koedam, N.; Block, T. A discourse an alytical perspective on sustainability assessment: Interpreting sustainable development in practice. Sustain. Sci. 2013, 8, 187-198. [CrossRef]

50. Sidiropoulos, E. Education for sustainability in business education programs: A question of value. J. Clean. Prod. 2014, 85, 472-487.

51. Belz, F.M. Sustainability Marketing: Blueprint of a Research Agenda; Technische Universität München: Munich, Germany, 2005; pp. $10-11$.

52. Kumar, V.; Rahman, Z.; Kazmi, A.A. Sustainability marketing strategy: An analysis of recent literature. Glob. Bus. Rev. 2013, 14, 601-625. [CrossRef]

53. Abzari, M.; Shad, F.S.; Sharbiyani, A.A.A.; Morad, A.P. Studying the effect of green marketing mix on market share increase. Adv. Environ. Biol. 2013, 7, 2981-2991.

54. Garg, A. Green marketing for sustainable development: An industry perspective. Sustain. Dev. 2015, 23, 301-316. [CrossRef]

55. Khan, A.; Bibi, S.; Lorenzo, A.; Lyu, J.; Babar, Z.-U. Tourism and development in developing economies: A policy implication perspective. Sustainability 2020, 12, 1618. [CrossRef]

56. Hall, M.; Göosling, S.; Scott, D. (Eds.) The global effects and impacts of tourism. An overview. In The Routledge Handbook of Tourism and Sustainability; Routledge: London, UK, 2015.

57. Haller, A.-P.; Butnaru, G.I.; Tacu Hârșan, G.D.; Ştefănică, M. The Relationship between Tourism and Economic Growth in the EU-28. Is There a Tendency towards Convergence? Available online: https://www.tandfonline.com/doi/full/10.1080/1331677X 2020.1819852? scroll=top\&needAccess=true (accessed on 12 June 2021).

58. Cătoiu, I. (coordinator); Cercetări De Marketing-Tratat; Uranus: Bucharest, Romania, 2009.

59. Parasuraman, A.; Zeithaml, V.A.; Berry, L.L. Servqual: A multiple-item scale for measuring consumer perc. J. Retail. 1988, 64, 12-40.

60. Ajzen, I. The theory of planned behavior. Org. Behav. Hum. Dec. Process. 1991, 50, 179-211. [CrossRef]

61. Ceptureanu, S.I.; Ceptureanu, E.G.; Olaru, M.; Popescu, D. An exploratory study on knowledge process barriers in oil industry. Energies 2018, 11, 1977. [CrossRef]

62. Ceptureanu, S.I.; Ceptureanu, E.G.; Visileanu, E. Comparative analysis of small and medium enterprises organizational performance in clothing industry. Ind. Text. 2017, 68, 156-162. 